This item was submitted to Loughborough's Research Repository by the author.

Items in Figshare are protected by copyright, with all rights reserved, unless otherwise indicated.

\title{
The sport, development and peace sector: a model of four social policy
} domains

PLEASE CITE THE PUBLISHED VERSION

http://dx.doi.org/10.1017/S0047279410000930

PUBLISHER

(c) Cambridge University Press

VERSION

AM (Accepted Manuscript)

LICENCE

CC BY-NC-ND 4.0

REPOSITORY RECORD

Giulianotti, Richard. 2019. "The Sport, Development and Peace Sector: A Model of Four Social Policy Domains". figshare. https://hdl.handle.net/2134/15497. 
This item was submitted to Loughborough's Institutional Repository (https://dspace.lboro.ac.uk/) by the author and is made available under the following Creative Commons Licence conditions.

\section{creative
commons}

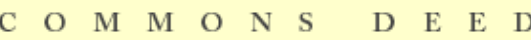

Attribution-NonCommercial-NoDerivs 2.5

You are free:

- to copy, distribute, display, and perform the work

Under the following conditions:

Attribution. You must attribute the work in the manner specified b the author or licensor.

Noncommercial. You may not use this work for commercial purposes.

No Derivative Works. You may not alter, transform, or build upon this work.

- For any reuse or distribution, you must make clear to others the license terms of this work.

- Any of these conditions can be waived if you get permission from the copyright holder.

Your fair use and other rights are in no way affected by the above.

This is a human-readable summary of the Leqal Code (the full license).

\section{Disclaimer 만}

For the full text of this licence, please go to: http://creativecommons.org/licenses/by-nc-nd/2.5/ 


\title{
The Sport, Development and Peace Sector: A Model of Four Social Policy Domains
}

\author{
Richard Giulianotti \\ This is a copy of the Author's Original Text of an article whose final and definitive from, the \\ Version of Record, has been published in Journal of Social Policy [copyright Cambridge University \\ Press], DOI: $10.1017 /$ S0047279410000930 \\ To Cite: Giulianotti, R., (2011) The Sport, Development and Peace Sector: A Model of Four \\ Social Policy Domains, Journal of Social Policy, 40:4, 757-776. \\ Published Version Available At: \\ http:/ /journals.cambridge.org/action/displayAbstract?fromPage $=$ online\&aid $=8359839 \&$ fileId $=$ \\ $\underline{\text { S0047279410000930 }}$
}

\begin{abstract}
This paper examines the 'sport, development and peace' (SDP) sector which has grown substantially at a global level over the past decade. The SDP sector is located conceptually within the broader 'global civil society', a highly contested policy field that features diverse political actors and ideologies. The main discussion sets out four ideal-types within the SDP policy domain that tend to be associated with specific institutions: first, neo-liberal social policies, as embodied by private or commercial interests, such as transnational corporations and forms of 'corporate social responsibility'; second, 'developmental interventionist' policies associated with non-governmental and community-based organisations; third, 'strategic developmentalist' policies associated with national and international governmental organisations, and sport federations; and, fourth, social justice policies associated with new social movements and critical NGOs. Each of these domains is examined in detail. Three main types of interrelationship across the domains are then identified. The paper concludes by arguing for a more sophisticated understanding of sport's policy capabilities, stronger cross-domain partnerships and a renewal of the SDP sector through a fresh focus on social justice issues.
\end{abstract}

\section{Introduction}

In recent years, sport has come to be viewed by policy-makers as an increasingly useful tool for advancing a wide range of policies on social welfare and development. In the UK, sports-based intervention strategies have been utilised to facilitate various social benefits, including community cohesion (by enabling inter-ethnic social contacts through sporting events), crime reduction (by organising sports activities for young offenders) and social integration (by using sports to draw people into education, employment and training). ${ }^{1}$ The most systematic and important growth in sport's social policy role has occurred at international level through the 'sport, development and peace' (hereon, SDP) sector. The SDP sector has received strong 
financial, political and organisational support from the United Nations, the European Union and many national governments. SDP agencies and projects are now located across the world, particularly in the Global South, and utilise sport to pursue diverse welfare objectives which often centre on the Millennium Development Goals.

The SDP sector, and indeed sport as a whole, has received very little consideration from social policy analysts. Arguably, this omission should be addressed for several reasons.

First, sport's social policy relevance is underscored by the welfare goals of SDP projects including, for example, facilitating peace and conflict resolution in divided societies; counteracting racism, intolerance and prejudice; promoting health education, gender equality and the integration of marginalised communities; and tackling crime and social exclusion in specific localities (Armstrong, 2004, 2007; Calloway, 2004; Darnell, 2008; Gasser and Levinsen, 2004; Höglund and Sunberg, 2008; Keim, 2003; Lea-Howarth, 2006; SDP IWG, 2008; Willis, 2000).

Second, national governmental and intergovernmental organisations are key players in building the SDP sector. For example, in the UK, the Department for International Development (DfID) has backed the '1Goal' campaign to promote universal children's education; the publicly funded agency, UK Sport, has an 'international sport development' division that assists SDP projects particularly in southern Africa; and the British Council now runs an extensive sport development programme to 'promote cross-cultural relations'. ${ }^{2}$ At global level, the United Nations listed 2005 as its International Year of Sport and Physical Education, with especial concentration on development and peace initiatives (UN General Assembly, 2006), and subsequently established the UN Office on Sport for Development and Peace (UNOSDP). In turn, UN agencies and funds such as the UNDP, UNICEF and UNHCR have become increasingly involved in SDP work. $^{3}$

Third, analysis of SDP work illuminates the different institutional and ideological forces that shape policy agendas and debates. Key institutional actors within the SDP sector include not only national governmental and intergovernmental organisations, but also many nongovernmental and community-based organisations, sport federations and transnational corporations (TNCs) which run corporate social responsibility (CSR) programmes. These diverse institutions harbour distinctive policy orientations on human wellbeing, as reflected in different stances towards neo-liberalism or public interventionism (cf. Clarke, 2004; Clarke et al., 2007; Craig et al., 2004; Farnsworth and Holden, 2006; Taylor-Gooby, 2008). 
Fourth, this analysis of the SDP sector should help to enlarge social policy debates in respect of sport, leisure and 'global civil society'. Since the early study by Rowntree and Lavers (1951; see, in particular, Dean, 2006: 113), there has arguably been too little focus within the social policy community on the contribution of recreation and leisure to human wellbeing. This omission appears particularly glaring given widespread governmental emphasis in recent years on the policy role of sport and recreation in tackling obesity, mental illness, youth crime, low educational attainment, inter-ethnic conflicts and other social problems. Moreover, the concept of global civil society, which I introduce here, may be used to examine a wide range of social policy issues and questions that have transnational dimensions (cf. Kaldor, 2003a; Pfau-Effinger, 2005; Roginsky and Shortall, 2009). This concept also confirms our understanding of globalisation as a process that is complex, multi-faceted and politically contested - in contrast to its more simplified presentation by neo-liberals (Clarke, 2004: 29).

Building on these observations, I provide a preliminary analysis of the SDP sector within the social policy context, with particular reference to the principal ideological and institutional forces at play. The paper is separated into four main parts. I begin by explaining why it makes sense to talk of an SDP 'sector' and how this relates to the particular fields of peace and culture. Second, I locate the SDP sector within the policy context of global civil society. Third, I set out in detail a four-fold model of these ideological and institutional forces. To finish, I explore briefly some interconnections across the four domains within this model and consider how the SDP sector may develop in policy terms. I should underline that the paper's main purpose is to model four policy domains within the SDP sector. Thus, I do not intend to explore the specific development of SDP programmes per se.

The paper is essentially analytical in approach, but I draw at times upon three types of primary research which I have undertaken within the SDP sector: interviews and fieldwork with SDP officials and agencies in the Balkans, Germany, the Middle East, South Asia and Switzerland; consultancy work on SDP projects in the Middle East, South Asia and Europe; and various kinds of informal interviews with SDP officials at international conferences and symposia. The constraints of brevity mean that I am only able to use this empirical research in a selective way, to flesh out the model through reference to specific types of practice or project.

The overall discussion seeks to address the gap in social policy analysis of the SDP sector specifically and sport issues in general. I intend that the paper should help to expand the research terrain - both thematically and substantively - for social policy analysts. This discussion also has 
wider methodological benefits for social policy analysts in providing both a model that may be utilised to examine other research fields beyond sport and a 'middle-range' case study that may enhance understanding of global civil society.

\section{The SDP sector}

There are two reasons why the SDP field may be identified as a distinctive social policy 'sector'. First, in institutional terms, many institutions deploy the 'SDP' appellation to describe themselves and their work - for example, the UN's Office on Sport for Development and Peace (UNOSDP), the Inter-Agency Taskforce on Sport for Development and Peace (2003), Canadian Heritage's 'Sport for Development and Peace' section and UNESCO's 'Sport for Peace and Development' division. Second, SDP agencies are increasingly interconnected and reflexive about the sector's work. For example, the ISDPA (International Sport for Development and Peace Association) and the 'International Platform on Sport and Development' are both committed to bringing together international researchers and practitioners to enhance the sector's work. ${ }^{4}$ Many SDP conferences have been convened, notably the first and second Magglingen conferences (2003, 2005) on Sport and Development; the 'Peace and Sport' movement's annual forums in Monaco; the 2005 'Sport and Peace' conference co-convened by the UN and Russian government in Moscow; the 2009 UNESCO SDP conference in Kingston; and the 2010 ISDPA summit in Boston. ${ }^{5}$ As these events indicate, the theme of 'peace' is integral to the SDP sector. The UNOSDP has concentrated substantially on sport's role in peacebuilding and conflict resolution, for example by highlighting projects undertaken in West and Central Africa, Sri Lanka, Central America and Afghanistan. The British Council also assists peace-building sports initiatives in the Middle East and the Balkans.

Conversely, the role of 'culture' and cultural practices within the SDP sector is less evident. Many SDP projects focus solely on sport-based work with specific client groups, while other agencies also include wider cultural activities, such as painting, music, dance and theatre. Institutional connections between sport and culture are also uneven. For example, UNESCO's sizeable SDP activities are located within the agency's 'Social and Human Sciences' section and not its 'Culture' division. Additionally, UNESCO plays a key role in the UN's International Year for the Rapprochement of Cultures (2010), yet nothing in its year-long calendar of major activities has an explicit sport component. In the UK, sport and culture do both fall within the remit of the government's Department for Culture, Media and Sport; however, these two fields are strongly differentiated. Moreover, the department's focus is largely on the development of sport, rather 
than on sport for development; that latter work is instead backed by the Department for International Development. Thus, overall, although the connection of sport and culture is rather weak among relevant agencies and organisations, the SDP field appears to be a distinctive and increasingly reflexive policy sector in its own right, with peace-related work playing an integral part.

\section{Global civil society}

In this section, I turn to outline the concept of global civil society. Having its theoretical roots in Kantian social philosophy, the idea of a global civil society has been addressed in detail in recent years by diverse social scientists, partly because of the rise of new social, political and economic policies within an increasingly interdependent world (cf. Anheier et al., 2007; Bartelson, 2006; Chandhoke, 2005; Chandler, 2005; Kaldor, 2003a, 2003b; Keane, 2003; Munck, 2006; Roginsky and Shortall, 2009; Taylor, 2004).

Here, I follow Kaldor (2003b: 590-1) by understanding global civil society in strongly relational terms, as a policy 'platform' or political field wherein highly diverse institutional actors 'argue about, campaign for (or against), negotiate about, or lobby for the arrangements that shape global developments' (Kaldor, 2003b: 590-1). Global civil society is not a frozen policy terrain, but is instead in a perpetual state of becoming, as these diverse social forces battle to shape its constitution and direction (cf. Keane, 2003; Lipschutz, 1992). Historically, new social movements have played catalytic roles in defining and extending global civil society, with subsequent engagements from other institutional forces, notably national and intergovernmental organisations, non-governmental organisations (hereon, NGOs) and community-based organisations. However, it is worth underlining the diversity of forces at play. Global civil society is not populated exclusively by 'progressive' campaigning social forces, as it also houses extremist movements, pure free-marketeers, realpolitik politicians and others whose political credos do not necessarily prioritise social welfare or global human development (cf.Keane, 2003: 66-7;Munck, 2006: 326). In this discussion, I locate the SDP sector firmly within the highly contested field that is global civil society.

\section{The four SDP policy domains}

In the following, I present an ideal-type model of the SDP sector, featuring four distinctive policy domains, each of which harbours a particular kind of social policy perspective in regard to identifying and alleviating particular human wants and social needs. Each of these social policy 
perspectives is most obviously represented by a particular type of institution. The four policy domains, and their representative institutions, within this ideal type are:

- private/commercial institutions, associated with neo-liberal social policies, notably CSR;

- mainstream NGOs and community-based organisations, associated with developmental interventionist social policies;

- national and intergovernmental agencies and organisations, and sport federations, associated with strategic developmentalist social policies;

- new social movements and radical NGOs, associated with social policies centred on social justice.

The main aspects of the model are mapped out in Figure 1.

\author{
NEO-LIBERALISM \\ Transnational corporations (TNCs), corporate social \\ responsibility (CSR) \\ e.g.Nike, Coca-Cola
}

\section{STRATEGIC DEVELOPMENTALISM}

National governmental agencies and intergovernmental organisations, sport federations

e.g. UK Sport, DfID, British Council, UN, UNESCO, UNICEF, FIFA, IOC

\section{JUSTICE}

New social movements and radical NGOs

e.g.Clean Clothes Campaign, Nike Watch

\section{Figure 1. The SDP Social Policy Sector}

e.g. streetfootballworld, Right to Play

Three initial points should be made concerning the model's rationale. First, Kaldor (2003a: 145) associates NGOs with neo-liberalism on the grounds that these professionalised, 'tamed social movements' are complicit in implementing neo-liberal social policies. However, here I understand TNCs and CSR programmes (which Kaldor does not discuss) as the chief institutional embodiments and beneficiaries of neo-liberal policies. Additionally, I would argue that, within the SDP sector, mainstream NGO officials and institutions are not always 'tamed' by neo-liberalism; indeed, they often possess tense or conflicting relationships towards neo-liberal institutions and policies. Thus, I examine mainstream NGOs and community-based organisations with reference to their modus operandi, namely 'developmental interventionism'; 
conversely, NGOs that are more radical are discussed with reference to their advocacy of 'social justice'.

Second, the model presented here is a Weberian ideal-type. For Weber (1949: 90), ideal-types are 'unified analytical constructs' which encapsulate the varied tendencies, diffuse characteristics and underlying properties of particular social phenomena. Inevitably, an ideal-type cannot capture all of the complex features of any specific social phenomenon. Thus, many actual SDP organisations and institutions will possess complex and diverse properties, some of which are 'typified' within other policy domains. For example, some mainstream NGOs may have features that support 'strategic developmentalism', 'social justice' and 'neo-liberal' social policies, alongside their more expected 'developmental interventionist' properties. Despite these complexities, the ideal-type helps to illuminate the 'elective affinities' that underlie the relationships between specific kinds of institution and particular types of social policy within the SDP sector. Moreover, these complexities may actually enhance rather than detract from the insights gleaned from the ideal-type model, notably by clarifying further the distinctions between typologies per se (cf. Weber 1978: 23-4).

Third, the model's value lies in its differentiation and clarification of the policy philosophies and logics that underpin SDP institutions. The model does not assume that different domains within the SDP sector are hermetically sealed off from one another. Indeed, some highly distinctive institutional relationships have occurred across the four domains. However, the model does enable us to understand the relative balances of power between the four domains with respect to policy-making and policy-implementation in the SDP sector.

\section{The SDP sector: four social policy domains}

\section{Corporate/neo-liberalism}

Neo-liberal social policies within the SDP sector, and global civil society more generally, are most obviously associated with business corporations, particularly TNCs. Since the 1970s, there has been a potent global turn towards the neoliberalist credo that

human well-being can best be advanced by liberating individual entrepreneurial freedoms and skills within an institutional framework characterised by strong private property rights, free markets and free trade. (Harvey, 2005: 2) 
Signature neo-liberal policies of deregulation, privatisation and the 'rolling back' of welfare services have been accompanied by the idealisation of a global 'private sphere', which imagines choice-making individual consumers being serviced by TNCs across borderless markets (Aldridge, 2005; Clarke, 2004; Clarke et al., 2007; Greener, 2008). The reality in terms of social policy, however, is rather more complex, as many public services are reconfigured within 'public-private partnerships' or the 'for-profit' sector (Clarke, 2004: 35-6; Farnsworth and Holden, 2006).

One social policy within neo-liberalism, often overlooked, concerns the promotion of private philanthropy. The CSR sector plays strongly to that personalised, choice-based policy credo, while also advocating the voluntary self-regulation of corporate social practices, in direct contrast to policies of public scrutiny and intervention (cf. Tonkiss, 2006: 72-3).

CSR's rapid expansion has been largely inspired by the need to head off anti-TNC campaigns by new social movements, radical NGOs and community-based organisations, focusing particularly on injustices in the Global South. Nevertheless, many corporations justify CSR programmes in strongly commercial terms, as good for productivity and profitability (Kotler and Lee, 2005; Financial Times, 20 April 2005). The United Nations has helped to legitimise CSR, notably through its 'Global Compact', enabling companies to work voluntarily with it and other agencies to promote the social good. For some critics, however, such agreements constitute 'a substitute for public regulation, an attempt to sidestep the diplomatic difficulties of dealing with the nasty bits of internationalized capitalism' (Rowe, 2005: 131).

Sport CSR programmes are often underpinned by neo-liberal logics. For example, the Nike Responsibility programme, states:

The opportunity is greater than ever for corporate social responsibility principles and practices to deliver business returns and to become a driver of growth ... Corporate responsibility must evolve from being seen as an unwanted cost to being recognized as an intrinsic part of a healthy business model, an investment that creates competitive advantage and helps a company achieve profitable, sustainable growth. ${ }^{6}$

CSR within the SDP sector tends to take three forms. First, radical NGOs and community-based organisations, new social movements and critical journalists have campaigned against the exploitative production techniques of sport merchandise corporations such as Nike, Reebok and Adidas (cf. Connor, 2001; Klein, 2000; Smith and Westerbeek, 2007: 6-7; Yimprasert, 2006). The response of TNCs - in developing their own monitoring and social responsibility programmes - 
has been at the vanguard of the CSR movement as a whole. For example, Reebok hired an Indonesian research company to report on conditions inside production factories (see IHS, 1999), while Nike's self-report strategies have been widely documented, debated and challenged. ${ }^{7}$ Inevitably, most CSR is 'nonpolitical', inherently voluntarist and strong on PR. Thus, SDP CSR strategies tend to feature celebrity-endorsed initiatives that deal with highly mediatised social dramas, rather than engage with long-term structural issues and problems.

Second, to finance and implement SDP work, some TNCs have collaborated closely with the most pragmatic or 'co-opted' NGOs and community-based organisations (cf. Kaldor, 2003a; Phillips, 2007). For example, the Laureus foundation - which runs SDP projects around the world, features elite athletes as 'academy members' and hosts glamorous 'world sport award' events - is prominently financed by TNCs such as Daimler, Mercedes, Richemont, IWC Schaffhausen and Vodaphone. ${ }^{8}$ These outlays are more than reimbursed by constant PR images that conflate 'good causes', elite athletes and sponsored brands. Corporations tend to favour SDP initiatives where real 'impact' is dramatised to capture public imaginations: for example, through delivering large volumes of sport equipment into impoverished communities. This arrangement places TNCs in strong positions to maximise marketing 'yield' from their sponsoring role and to influence the objectives, implementation and results dissemination of SDP projects.

A third arrangement involves more systemic ties between TNCs and national governmental and intergovernmental organisations to assist with SDP programmes. For example, the UN has highlighted Nike and Reebok participation in the 'Global Compact', Nike and Cartier have contributed materially to UNHCR SDP projects and sport federations have drawn TNC sponsors into SDP initiatives. Symbolically too, reflecting their underlying corporate orientation, some sport federations have explicitly titled their SDP departments as CSR divisions.

Overall, CSR programmes institutionalise neo-liberal, voluntarist policies in pursuing social goals at local, national and transnational levels. The SDP sector provides a premier site for the contemporary implementation of CSR programmes and for TNC participation within the broad global civil society. Like other policy sectors, the SDP field features some distinctive 'publicprivate' partnerships, particularly at institutional level, as TNCs both shape and benefit directly from working with other agencies (Clarke, 2004: 35-6; Farnsworth and Holden, 2006). 
NGOs and community-based organisations have mushroomed numerically since the early 1980s, such that some analysts identify international NGOs as the principal actors within global civil society (Lechner, 2009: 161). NGOs and community-based organisations encompass an enormous variety of associations, including religious bodies, hobby and sports groups, youth movements and higher education institutions, as well as organisations committed to progressive transnational politics on development, peace and social justice (Boli and Thomas, 1999).

In the SDP sector, mainstream NGOs and community-based organisations are diverse, but tend to advocate particular developmental interventionist themes such as the right to intervene when the personal safety of individuals is threatened, the value of sport as a tool of intervention and the critical role of building human capacity and public participation within underdeveloped settings. Unlike the other three domains within the SDP sector, it is the agencies themselves which implement sport-related interventions, usually with support from outside institutions. Thus, mainstream NGOs and community-based organisations stake claims to professional competence and expertise, in order to justify the value and legitimacy of targeted interventions. In recent years, many mainstream NGOs and community-based organisations have responded to concerns over the short-term and insubstantial impact of SDP interventions (cf. Armstrong, 2007; Hognestad and Tollisen, 2004). 'Capacity-building' and 'sustainability' are now established watchwords, particularly among agencies that favour the 'training the trainers' method, whereby local people are trained to teach SDP principles and techniques to wider social groups at grassroots level. ${ }^{10}$

Mainstream NGOs and community-based organisations in the SDP sector may be differentiated by their sport-specific or generalist focuses. Sport-specific organisations, founded to undertake SDP work, include the Danish NGO 'Open Fun Football Schools', which uses football to build social contacts in divided regions (notably the Balkans); UK Sport Relief, which finances and implements sport projects in developing nations; and the Kicking AIDS Out network, which disseminates health messages through sport clinics across southern Africa. ${ }^{11}$ Conversely, generalist NGOs and community-based organisations predate their SDP work, which tends to be used among a wide range of interventionist techniques. Illustrations here include Action Aid's use of sport in projects in Afghanistan, Brazil and other locations, and the sport-related, peacebuilding work of mainstream NGOs in Sri Lanka, such as FLICT and Sarvodaya.

SDP mainstream NGOs and community-based organisations are differentiated by scale and power. Some sport-specific NGOs are highly transnational and oversee networks of locally 
based organisations which implement SDP projects. For example, the Berlin-based NGO streetfootballworld coordinates over 80 local projects in more than 40 nations. In line with Geyer's (2001: 479-81) findings on NGOs within the EU system, officials from smaller NGOs and community-based organisations who were interviewed as part of this research reported their deep concerns on the politics of the SDP system, particularly how large, pragmatic agencies were too influential, media-orientated and business-like in dealings with large donors.

Mainstream NGOs and community-based organisations are further differentiated by professional philosophies, methods and SDP objectives. Some organisations are associated with neo-liberal, voluntarist and philanthropic approaches; for example, the US-based 'Athletes for Hope' movement, largely driven by former athletes, aspires 'to make a difference and to inspire others to pass their passion for philanthropy from generation to generation'. ${ }^{12}$ Conversely, small agencies often adopt 'facilitating' rather than interventionist roles, for example by staging workshops that enable local people to assess their own needs. Moreover, these organisations also display diverse methods of engagement with prospective user groups, ranging from limited consultative processes to full dialogue with officials and local peoples (cf. Darnell, 2008; Hognestad and Tollisen, 2004).

Relations with donors vary substantially. Some large NGOs and community-based organisations have close financial and political links to specific funding bodies (such as international sport federations, national governments and intergovernmental organisations) that are committed to long-term SDP initiatives. Examples here include streetfootballworld's ties with FIFA (world football's governing body), or Right to Play (formerly known as Olympic Aid) with the International Olympic Committee. Smaller agencies are wary of influences exerted by large institutional benefactors. However, in appreciating the dangers of being 'tamed' or 'co-opted', many organisation officials are highly reflexive about the underlying tensions between the twin needs of policy influence and professional principle (cf. Kaldor, 2003a; Phillips, 2007). In line with Craig et al.'s (2004) findings on the voluntary sector, many organisational officials seek to reconcile 'insider' and 'outsider' statuses. In outsider mode, my research found that officials from one organisation insisted that they retain decision-making independence, strong 'grassroots' ties and commitments to original goals; indeed, some officials stated that it is the donors which adapt to the SDP field rather than the other way round. As 'insiders', mainstream NGOs and community-based organisations emphasise the benefits of being 'taken seriously' by powerful IGOs (e.g. United Nations, European Union, World Bank) or major corporations, and thus 
being well-positioned to generate funding and to shape policies and practice across the SDP sector.

One final variation across mainstream NGOs and community-based organisations concerns their ideological and political relations across policy agendas. Often depending on context and issue, some generalist NGOs and community-based organisations slot into the 'radical NGO' category (discussed later) which advocates progressive social rights and stages campaigns against sport federations, corporations and state bodies. For example, Amnesty International, Human Rights Watch and other human-rights NGOs attacked the award of the 2008 Olympics to Beijing and mounted extensive campaigns against China and the IOC. Elsewhere, labour organisations have led campaigns against specific kinds of worker abuse by sport-related TNCs. However, in broad terms, mainstream NGOs tend to prioritise the pragmatic implementation of SDP interventions and do not confront social justice questions even where corruption or serious human rights abuses taint potential partners. This 'apolitical' approach appeals to powerful donors and provides opportunities for insider influence upon SDP policy. More subtly, where the SDP agency implements peace-building and reconciliation projects, a non-political and 'neutral' stance can also help to build user-group trust.

Overall, SDP developmental interventionism features diverse mainstream NGOs and community-based organisations, differentiated particularly by scale and power. Organisations that are decidedly 'mainstream', large or close to strategic partners (such as TNCs and national governmental and intergovernmental organisations) tend to be 'tamer', but may retain insider policy-influence. Organisations that are more radical, smaller, selective in donor relationships, or with substantial SDP histories, tend to have more distinctive and critical standpoints on SDPrelated practices and are more likely to identify new policy issues for the sector as a whole. Some sport-focused organisations, as in other policy sectors, endeavour to merge insider and outsider statuses, by maintaining core values while extending their influence. Finally, the recent 'mainstreaming' of the SDP sector has drawn many general organisations into sport-related work. Some SDP agencies consider they may provide future models of good practice for organisations across global civil society. However, officials with long-standing involvement in development work may be critical of some SDP agency practices, such as glossy PR awards events or partnerships with TNCs that have poor civil-society or industrial-relations records. 
National and intergovernmental organisations have exercised significant organisational power within the SDP sector over the past decade. The UN's commitment to sport in 2005, noted earlier, crystallised and intensified the involvement of national and intergovernmental organisations in sport and drew the SDP sector more fully into the mainstream global development field.

National and intergovernmental organisations tend to pursue strategic developmentalist SDP policies in two ways. First, SDP agencies typically share the objectives of wider national governmental and intergovernmental organisations, particularly in prioritising the Millennium Development Goals (cf. UN Inter-Agency Taskforce on Sport for Development and Peace, 2003: 7-8). Additionally, some national governmental and intergovernmental organisations, notably UNICEF, have advocated sport per se as a human and social right.

Second, strategic developmentalism is registered in the methods of national governmental and intergovernmental SDP programmes, particularly in building institutional networks and facilitating knowledge transfer such as by convening major sectoral conferences. For example, the Peace and Sport organisation in Monaco has convened annual forums since 2007, featuring NGOs, national governmental and intergovernmental organisations and TNCs. During 2005, the United Nations convened various international symposia on SDP issues as part of its International Year of Sport and Physical Education. Some national governmental and intergovernmental organisations deploy websites to facilitate knowledge transfer, such as contact details for SDP agencies and 'toolkits' to guide NGOs and community-based organisations in implementing specific projects.

SDP national governmental and intergovernmental organisations fall into three broad categories. First, intergovernmental organisations, such as the United Nations and its various agencies, have engaged with sport, notably since the UN's 2005 initiative, the foundation of the UN's InterAgency Taskforce on Sport for Development and Peace and the appointment of a Special Advisor to the Secretary-General on Sport for Development and Peace. UN agencies, programmes and funds have been engaged in SDP work. For example, UNESCO has its own SDP portal, assists various projects (especially peace-building ones) and runs a working group on the developmental aspects of sport and physical education; UNICEF's SDP division supports various programmes and institutional collaborations; and UNAIDS has a set of 'sports partnerships' within its anti-AIDS educational programmes. ${ }^{13}$ Elsewhere, the Conseil 
International du Sport Militaire (CISM), which organises military sports among more than 130 member nations, controls a 'sport for peace' division aimed particularly at peacekeeping forces. ${ }^{14}$

Second, sport federations and institutions hold substantial SDP commitments. FIFA's 'Football For Hope' movement, implemented through the NGO streetfootballworld, has five main SDP themes, building health, peace, children's rights and education, environment and antidiscrimination; it aims to found over 100 sustainable projects worldwide. At national level, SDPactive sport federations include the Jordanian Olympic Committee (through its Peace Through Sport programmes), and the football association and Olympic committee in Sri Lanka which have provided technical support for UNDP initiatives.

Third, many national governmental agencies undertake SDP work. For example, the British Council's dedicated sport unit conducts SDP work across over 40 nations and includes the 'International Inspiration' and 'Dreams + Teams' initiatives. ${ }^{15}$ Its Belgrade office published a bilingual SDP manual and convened a major conference on sport and peace. UK Sport has an international development division that promotes education, equity, HIV/AIDS awareness and good governance through sport, particularly in sub-Saharan Africa. Elsewhere, Canadian Heritage and the Canadian International Development Agency have invested in several SDP projects overseas, particularly Commonwealth and la Francophonie nations (Darnell, 2008). In Germany, national governmental ministries have supported financially the streetfootballworld network.

Of course, these three categories are not hermetically sealed, but routinely overlap. For example, the United Nations and FIFA strategic alliance, since 1999, has facilitated collaborative work between football's governing body and UNICEF; and the Barcelona football club pays $€ 1.5$ million annually to wear UNICEF's logo across team shirts.

Overall, strategic developmentalism is characterised by top-down management and networkbuilding techniques for knowledge transfer across the SDP sector. National governmental and intergovernmental organisations are key players in 'universalising' SDP work and in shaping the sector's principal policy focus on meeting fundamental needs and targeting MDGs. National governmental and intergovernmental organisations routinely build partnerships with TNCs, NGOs and community-based organisations and mirror the practices of these other institutional types, for example by using high-profile athletes as campaign ambassadors or project champions or defining their own SDP work as 'corporate social responsibility'. National governmental and intergovernmental organisations provide a particularly powerful bridge between the SDP sector 
and the wider global civil society, but the longer-term substance of their social policies remains unclear.

\section{New social movements and radical NGOs/social justice}

Social policies centred on social justice within the SDP sector, and in global civil society more generally, are associated with new social movements and radical NGOs, primarily those located in the Global North. In the past two decades, transnational struggles over social justice have been crystallised by mass public protests at major meetings of the world's political and economic powers (Farnworth, 2003; Held and McGrew, 2002) and in the establishment of the World Social Forum' (Fisher and Pooniah, 2003). New social movements and radical NGOs crystallise popular resistance towards the global imposition of neoliberal policies and the post-9/11 diffusion of new military-industrial complexes by the United States and its allies. In democratic and political terms, new social movements and radical NGOs confront and challenge state and corporate strategies that 'dissolve' the public realm and wreak a 'creative destruction' upon old forms of collective solidarity (Clarke, 2004; cf. Rodger, 2003). These movements may also be located among historic 'anti-systemic' forces which have also included workers' movements, the suffragettes and 1960s civil rights movements (cf. Wallerstein, 2003: 39-40). In this sense, new social movements and radical NGOs pursue social justice for marginalised groups through the extension of rights, as part of the ongoing struggle to extend democracy across the transnational public sphere (Habermas, 2001; Shute and Hurley, 1993). Thus, in social policy terms, these movements encapsulate the critical response of civil societies to the failure of nation-states, intergovernmental organisations and TNCs to remove practices and structures which undermine the human rights of vulnerable populations.

Overall, unlike the other three domains, the social justice field is not defined in the main by formal institutions, but instead also constitutes a policy-advocating space that is inhabited by diverse individuals and social networks, such as political activists, investigative reporters and academics. In the SDP field, new social movements such as 'Nike Watch' and the 'Clean Clothes Campaign' have led political movements against exploitative and oppressive practices in factories that produce sport apparel, thereby, as I have noted, pressing the relevant corporations to address these practices and to engage with the SDP sector. Some social movements, radical NGOs, critical academics and journalists have highlighted other injustices in global sport, such as the abusive treatment of young athletes in 'youth development' academies within developing 
nations, and corruption and human rights abuses within sport federations (Marcano and Fidler, 2002). ${ }^{16}$

Many movements and radical NGOs are not solely focused on opposition, but also advocate progressive social policies, such as the protection and extension of civil and human rights in employment, and consciousness-raising campaigns to promote tolerance of minority groups and ethical consumerism. However, social justice movements face more significant difficulties and threats than organisations within other domains of the SDP sector. These movements are still underdeveloped and relatively isolated from each other, in part because they are context-specific. There is also a substantial disconnection between these SDP agencies and the wider global civil society to an extent that is not found in the other three domains. Thus, for example, whereas leading sport officials have contributed to the World Economic Forum, sport-related issues are hardly addressed at World Social Forums. Moreover, the focus of many sports-focused new social movements and radical NGOs is on largely 'developed world' issues, involving campaigns against expensive bids by cities to host major sport events, the growing legal regulation of sport fans and racism, sexism, homophobia and religious bigotry inside stadiums (cf. Lenskyj, 2008). ${ }^{17}$ It is often difficult to identify connections or direct common causes between these movements and those that focus on Global South issues.

Overall, the SDP social justice domain is dominated by new social movements and radical NGOs. Of all the four SDP domains, social justice features 'outsider' agencies with the weakest direct influence in shaping broad SDP policy and the lightest volumes of social capital, in institutional and interpersonal terms, vis- $a$-vis other kinds of SDP organisation. Thus, new social movements are rarely invited to participate in conventions led by national and intergovernmental organisations, or to contribute to projects funded by TNCs or implemented by mainstream NGOs and community-based organisations. New social movements and radical NGOs are best placed to reflect critically both on the contribution of sport to meeting specific social policy objectives and on sport's negative social effects within particular contexts (e.g. the ties between major sport institutions, exploitative corporations and oppressive regimes). However, compared to other SDP domains, agencies associated with social justice have two key positional weaknesses: first, they lack effective internal integration and coordination; second, they remain weakly positioned vis- $a$-vis the wider global civil society. These weaknesses underscore the difficulties faced by social justice agencies in having more than localised impacts upon the definition and development of the SDP sector. 


\section{SDP social policy domains: interactions and future developments}

In this discussion, I have mapped out the four main social policy domains within the SDP sector, which is itself located within the wider context of global civil society. The broad aim here has been to address gaps in the field of social policy in regard to specific analysis of the SDP sector and more general consideration of sport per se. The model provided here may be used to map the relevant forces that seek to shape other policy fields, for example in relation to housing, employment or international development. As an ideal type, the model cannot capture all of the complex features within SDP agencies. However, its main purpose is to illuminate the close affinities between specific kinds of SDP institution and particular types of social policy. The model registers the divergent and often competing policy solutions advocated by different institutions within the sector. For many institutions, particularly TNCs but increasingly national governmental and intergovernmental organisations and non-sport NGOs and community-based organisations, the SDP sector provides a very important field for their engagement with global civil society.

Three main forms of articulation occur between the four domains. First, specific individuals or institutions may switch across the four domains, largely to gain financial security and stronger influence in shaping the SDP sector. In line with Kaldor, the trend is towards individuals and institutions entering into mainstream practice, for example as new social movements become more pragmatic NGOs, or as volunteers with radical NGOs and community-based organisations take up employment within pragmatic organisations, national governmental and intergovernmental organisations, or CSR agencies. However, the SDP sector is a relatively small field, wherein career patterns will invariably criss-cross across national governmental and intergovernmental organisations, NGOs, community-based organisations and CSR divisions. Moreover, the process is not always one-way, as some individuals switch from strategic roles within CSR agencies, NGOs or community-based organisations and back to grassroots SDP work that engages more with social justice issues.

Second, some agencies associated with one policy domain have drawn institutions from elsewhere in global civil society more fully into the SDP sector. I noted earlier how the UN served to legitimise the SDP sector across global civil society, so encouraging participation by mainstream NGOs and community-based organisations and TNCs. Additionally, the rightsbased campaigns of new social movements and radical NGOs have drawn national governmental and intergovernmental organisations, softer NGOs and TNCs into confronting 
specific issues within the SDP sector. For example, in the mid-1990s, the widespread use of child labour to produce footballs in Pakistan was highlighted by radical NGOs and labour unions, pressing a variety of national governmental and intergovernmental organisations (notably the Pakistan government and UN agencies), sport federations (notably FIFA) and sport TNCs into working together to stop this practice (Kazmi and Macfarlane, 2003; Tabusa, 2000: 267).

Third, some SDP institutions embody major elements of several different domains. For example, the Swiss-based 'International Platform on Sport and Development' is an 'online resource and communication tool' that combines the strategic developmentalism of national governmental and intergovernmental organisations (in working closely with policy-makers, such as the UN, and providing knowledge-transfer platforms), the developmental interventionism of NGOs and community-based organisations (through close personal and professional ties to agencies that implement programmes) and links to neoliberalism and CSR (through private-sector sponsorships and partnerships). ${ }^{18}$

Looking ahead, the SDP sector faces three main challenges in the effective expansion of sportrelated social policies. First, some institutions that have links to all four domains - but particularly those featuring national governmental and intergovernmental organisations and TNCs/CSR programmes - need to develop more sophisticated understandings of sport's policy capabilities if the SDP sector is to thrive. One problem is that some sport federations and intergovernmental organisations are apt to essentialise sport's inherent 'goodness', without fully understanding how the meanings and usages of sport must be located in historical, political and policy terms. The need to de-essentialise and to 'ground' sport has particular ramifications for SDP work in conflict zones. In regions such as Afghanistan, the Balkans, the Middle East and West and Central Africa, various national governmental and intergovernmental organisations, NGOs, community-based organisations and sport federations have seized upon the relatively neutral political identity of sport to accord SDP initiatives a key role in social policies that are intended to build cross-community social relations, reconciliation and socio-political stability. One threat is that, if its essentialist understanding lingers within the SDP sector, sport may come to be viewed by marginalised communities as complicit with dominant interests, for example as an instrument of Western 'soft power' across the Middle East. In such circumstances, the longterm implementation of SDP work would be jeopardised.

Second, the SDP sector needs to explore how new types of partnership may be established across the four different social policy domains. The marginal position of the social justice 
approach might be addressed, particularly by SDP institutions such as national governmental and intergovernmental organisations that are committed to building networks and knowledge transfer. New partnerships may also be developed between mainstream NGOs, communitybased organisations and new social movements.

Following from this, and third, the SDP sector might return its focus to social justice issues in order to move its policy objectives beyond the current emphasis on meeting immediate human needs or pursuing the UN's Millennium Development Goals. Indeed, there are signs that key SDP institutions have slipped behind other prominent forces across global civil society in regard to social justice issues. For example, the SDP sector may revisit its earlier and highly beneficial interest in social justice issues surrounding the production of sport merchandise in developing nations. There is clear evidence that sport organisations have been eclipsed by major institutions within the public sector - such as city authorities or universities - which have established themselves as 'Fair Trade' entities. One way ahead in the SDP sector would be for new social movements, national governmental and intergovernmental organisations (such as the UN), NGOs and community-based organisations to press sport federations and the business sector to move beyond the 'self-regulation' of sport production by TNCs, and instead to adopt the policy that only 'Fair Trade' equipment or commodities should be utilised or on sale at specific sport tournaments. This sort of policy would give greater substance to the universalistic discourses and humanitarian slogans that are widely used by sports federations. It would help to enhance sport's prominence in regard to social justice and the broader global civil society. It would also enable a fresh set of welfare and developmental principles to be forged across a revivified SDP sector.

\section{Acknowledgements}

The research for this paper was supported by the Nuffield Foundation. I would like to thank the journal editors, two referees, and Tim Blackman, Dave Byrne and Gary Craig for their very helpful comments on earlier versions of this paper.

\section{Notes}

\footnotetext{
${ }^{1}$ See, for example, http://www.cohesioninstitute.org.uk/Resources/Toolkits/Sport; http://www.nacro.org.uk/services/dorset/nacro-bournemouth-football-4-all/; http://www.streetleague.co.uk/aboutus.htm.

${ }^{2}$ See http://www.dfid.gov.uk/Media-Room/News-Stories/2009/1GOAL-Education-ForAllcampaign-launched-at-Wembley-Stadium/; http://www.uksport.gov.uk/pages/international_development/; http://www.britishcouncil.org/sport.htm.

${ }^{3}$ http://www.unicef.org/sports/index.html; http://www.unhcr.org/pages/4a0d90946.html.

${ }^{4}$ See http://isdpaonline.ning.com/; http://www.sportanddev.org/.
} 
${ }^{5}$ See http://www.un.org/sport2005/newsroom/second_magglingen_conference.pdf; http://www.peace-sport.org/gb/press.htm; http://www.un.org/sport2005/newsroom/sport_and_peace.htm; http://unesdoc.unesco.org/images/0018/001821/182180E.pdf; http:/ /isdpaonline.ning.com/page/power-of-sport-summit.

${ }^{6}$ See http://www.nikebiz.com/responsibility/.

${ }^{7}$ See for example http://www.businessweek.com/magazine/content/06 48/b4011001.htm; http://www.corpwatch.org/article.php?id=966; http://www.globalexchange.org/campaigns/sweatshops/nike/stillwaiting.html.

${ }^{8}$ See http://www.laureus.com/.

${ }^{9}$ See

http://www.un.org/africa/osaa/UN\%20Secretariat\%20web\%20Links/UN\%20business\%20G1 obal $\% 20$ Compact $\% 20$ in $\% 20$ action.htm.

${ }^{10}$ See

http://iwg.sportanddev.org/data/htmleditor/file/SDP\%20IWG\%20Newsletters/SDP $\% 20 \mathrm{NE}$ WS\%20Vol2\%20Iss1.pdf. See also http://www.peace-sport.org/gb/burundi_actions.htm.

${ }^{11}$ See Gasser and Levinsen (2004); http://www.sportrelief.com/about/issue-spotlights; http://www.kickingaidsout.net/Sider/default.aspx.

${ }^{12}$ See http://www.athletesforhope.org/.

${ }^{13}$ See http://portal.unesco.org/shs/en/ev.php-

URL_ID=9624\&URL_DO=DO_TOPIC\&URL_SECTION=201.html;

http://portal.unesco.org/shs/en/ev.php-

URL_ID=9536\&URL_DO=DO_TOPIC\&URL_SECTION=201.html;

http://www.unicef.org/

sports/index.html;

http://www.unaids.org/en/Partnerships/Advocacy士partners/Sport/default.asp.

${ }^{14}$ See http://www.cism-milsport.org/eng/011_SPORT_FOR_PEACE/09_01-

01_main/2009_main.asp.

${ }^{15}$ See http://www.britishcouncil.org/sport.htm.

${ }^{16}$ The Danish NGO 'Play the Game' organisation, which has close ties to international journalists, has exposed corrupt practices among sport officials as part of its mission to 'encourage democracy, transparency, and freedom of expression in world sport'. See http://www.playthegame.org/about/our-goals.html.

${ }^{17}$ See, for example, Football Against Racism in Europe (http://www.farenet.org/default.asp?intPageID=6); Football Fans Against the Criminal Justice Act; the BAFF fanmovement in Germany (http://www.aktive-fans.de/); and Progetto Ultra in Italy (http://www. progettoultra.it/cms/).

${ }^{18}$ See http://www.sportanddev.org/about this platform/funding partners/.

\section{References}

Aldridge, A. (2005), The Market, Cambridge: Polity.

Anheier, H. K., Kaldor, M. and Glasius, M. (eds.) (2007), Global Civil Society Yearbook 2005/6, London: Sage.

Armstrong, G. (2004), 'The lords of misrule: football and the rights of the child in Liberia, West Africa', Sport in Society, 7: 3, 473-502.

Armstrong, G. (2007), 'The global footballer and the local war-zone: George Weah and transnational networks in Liberia,West Africa', Global Networks, 7: 2, 230-47. 
Bartelson, J. (2006), 'Making sense of global civil society', European Journal of International Relations, 12: 3, 371-95.

Boli, J. and Thomas, G. M. (eds.) (1999), Constructing World Culture, Stanford, CA: Stanford University Press.

Calloway, J. (2004), 'Leave no child behind: recreation and sports - instruments for world peace', Youth Studies Australia, 23: 1, 35-41.

Chandhoke, N. (2005), 'How global is global civil society?', Journal of World Systems Research, 11: 2, 355-71.

Chandler, D. (2005), Constructing Global Civil Society, Basingstoke: Palgrave.

Clarke, J. (2004), 'Dissolving the public realm? The logics and limits of neo-liberalism', Journal of Social Policy, 33: 1, 1-27.

Clarke, J., Newman, J., Smith, N., Vidler, E. and Westmarland, L. (2007), Creating CitizenConsumers: Changing Publics and Changing Public Services, London: Paul Chapman.

Connor, T. (2001), Still W aiting for Nike to Do It, San Francisco, CA: Global Exchange, accessed at http://www.globalexchange.org/campaigns/sweatshops/nike/NikeReport.pdf.

Craig, G., Taylor, M. and Parkes, T. (2004), 'Protest or partnership? The voluntary and community sectors in the policy process', Social Policy and Administration, 38: 3, 221- 39.

Darnell, S. (2008), 'Changing the world through sport and play: a post-Colonial analysis of Canadian volunteers within the "Sport for Development and Peace" movement', unpublished Ph.D. thesis, University of Toronto.

Dean, H. (2006), Social Policy, Cambridge: Polity.

Farnsworth, K. (2003), 'The Anti-Globalisation/Anti-Capitalist Movement: challenging governments and corporations', in G. Taylor and M. Todd (eds.), Democracy and Protest, London: Merlin Press.

Farnsworth, K. and Holden, C. (2006), 'The business-social policy nexus: corporate power and corporate inputs into social policy', Journal of Social Policy, 35: 3, 473-94.

Fisher, W. F. and Pooniah, T. (eds.) (2003), Another World is Possible, London: Zed.

Gasser, P. K. and Levinsen, A. (2004), 'Breaking post-war ice: open fun football schools in Bosnia and Herzegovina', Sport in Society, 7: 3, 457-72.

Geyer, R. R. (2001), 'Can European Union (EU) social NGOs co-operate to promote EU social policy?', Journal of Social Policy, 30: 3, 477-93.

Greener, I. (2008), 'Choice and voice - a review', Social Policy and Society, 7: 2, 255-65.

Habermas, J. (2001), The Postnational Constellation, Cambridge: Polity.

Harvey, D. (2005), A Brief History of Neoliberalism, Oxford: Oxford University Press.

Held, D. and McGrew, A. (2002), Globalization/Anti-Globalization, Cambridge: Polity.

Höglund, K. and Sundberg, R. (2008), 'Reconciliation through sports? The case of South Africa', Third World Quarterly, 29: 4, 805-18.

Hognestad, H. and Tollisen, A. (2004), 'Playing against deprivation: football and development in Nairobi, Kenya', in G. Armstrong and R. Giulianotti (eds.), Football in Africa, Basingstoke: Palgrave. 
Insan Hitawasana Sejahtera [IHS] (1999), Peduli Hak: Caring for Rights, Jakarta: IHS.

Kaldor, M. (2003a), Global Civil Society, Cambridge: Polity.

Kaldor, M. (2003b), 'The idea of global civil society', International Affairs, 79: 3, 583-93.

Kazmi, B. A. and Macfarlane, M. (2003), 'Elimination of child labour: business and local communities', in R. Sullivan (ed.), Business and Human Rights, Sheffield: Greenleaf.

Keane, J. (2003), Global Civil Society?, Cambridge: Cambridge University Press.

Keim, M. (2003), Nation Building at Play: Sport as a Tool for Integration in Post-Apartheid South Africa, Aachen: Meyer \& Meyer.

Klein, N. (2000), No Logo, Toronto: Knopf.

Kotler, P. and Lee, N. (2005), Corporate Social Responsibility, London: Wiley.

Lea-Howarth, J. (2006), 'Sport and conflict: is football an appropriate tool to utilise in conflict resolution, reconciliation and reconstruction?', MA Dissertation, University of Sussex, accessed at: http://archive.sportanddev.org/data/document/document/238.pdf.

Lechner, F. (2009), Globalization: The Making of World Society, Oxford: Wiley-Blackwell.

Lenskyj, H. (2008), Olympic Industry Resistance: Challenging Olympic Power and Propaganda, Albany, NY: SUNY Press.

Lipschutz, R. (1992), 'Reconstructing world politics: the emergence of a global civil society', Millennium, 21: 3, 389-420.

Marcano, A. J. and Fidler, D. P. (2002), Stealing Lives: The Globalization of Baseball and the Tragic Story of Alexis Quiroz, Indiana: Indiana University Press.

Munck, R. (2006), 'Global civil society: royal road or slippery path', Voluntas, 17: 4, 324-31.

Pfau-Effinger, B. (2005), 'Culture and welfare state policies: reflections on a complex interrelation', Journal of Social Policy, 34: 1, 3-20.

Phillips, R. (2007), "Tamed or trained? The co-option and capture of "favoured" NGOs', Third Sector Review, 13: 2, 27-48.

Rodger, J. J. (2003), 'Social solidarity, welfare and post-emotionalism', Journal of Social Policy, 32: 3, 403-21.

Roginsky, S. and Shortall, S. (2009), 'Civil society as a contested field of meanings', International Journal of Sociology and Social Policy, 29: 9-10, 473-87.

Rowe, J. K. (2005), 'Corporate social responsibility as business strategy', in R. D. Lipschutz and J. K. Rowe (eds.), Globalization, Governmentality and Government Politics, London: Routledge.

Rowntree, S. and Lavers, G. R. (1951), English Life and Leisure, London: Macmillan.

SDP IWG (2008), Harmessing the Power of Sport for Development and Peace: Recommendations to Governments, Toronto: Right to Play.

Shute, S. and Hurley, S. (eds.) (1993), On Human Rights, Oxford: Oxford University Press.

Smith, A. C. T. and Westerbeek, H. M. (2007), 'Sport as a vehicle for deploying corporate social responsibility', Journal of Corporate Citizenship, 25: 1-12.

Tabusa, S. (2000), 'Trade unions against child labour', in N. Haspels and M. Jankanish (eds.), Action against Child Labour, Geneva: ILO. 
Taylor, R. (ed.) (2004), Creating a Better World: Interpreting Global Civil Society, Bloomfield, CT: Kumarian Press.

Taylor-Gooby, P. (2008), 'Choice and values: individualised rational action and social goals', Journal of Social Policy, 37: 2, 1-19.

Tonkiss, F. (2006), Contemporary Economic Sociology, London: Routledge.

UN General Assembly (2006), Sport for Development and Peace: The Way Forward, Report of the Secretary-General, A/61/73, New York: United Nations.

United Nations Inter-Agency Taskforce on Sport for Development and Peace [UNOSDP] (2003), Sport for Development and Peace: Towards Achieving the Millennium Development Goals, New York: United Nations.

Wallerstein, I. (2003), The Decline of American Power, New York: New Press.

Weber, M. (1949), The Methodology of the Social Sciences, Glencoe, IL: Free Press.

Weber, M. (1978), Selections in Translation, Cambridge: Cambridge University Press.

Willis, O. (2000), 'Sport and development: the significance of Mathare Youth Sports Association', Canadian Journal of Development Studies, 21: 825-49.

Yimprasert, J. L. (2006), 'The life of football factory workers in Thailand', Thai Labour Campaign, accessed at: http://www.cleanclothes.org/documents/Life_football_workers_of_thailand.pdf. 